Received: 25 October 2017

Accepted: 27 February 2018

Published online: 16 March 2018
ENTIFIC REP

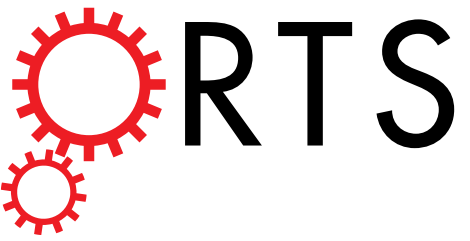

OPEN Active carbon sequestration in the Alpine mantle wedge and implications for long-term climate trends

Marco Giovanni Malusà $\mathbb{D}^{1}$, Maria Luce Frezzotti ${ }^{1}$, Simona Ferrando $\mathbb{D}^{2}$, Enrico Brandmayr $\mathbb{D}^{3}$, Fabio Romanelli $i^{4}$ \& Giuliano Francesco Panza ${ }^{5,6,7}$

The long-term carbon budget has major implications for Earth's climate and biosphere, but the balance between carbon sequestration during subduction, and outgassing by volcanism is still poorly known. Although carbon-rich fluid inclusions and minerals are described in exhumed mantle rocks and xenoliths, compelling geophysical evidence of large-scale carbon storage in the upper mantle is still lacking. Here, we use a geophysical surface-wave seismic tomography model of the mantle wedge above the subducted European slab to document a prominent shear-wave low-velocity anomaly at depths greater than $180 \mathrm{~km}$. We propose that this anomaly is generated by extraction of carbonate-rich melts from the asthenosphere, favoured by the breakdown of slab carbonates and hydrous minerals after cold subduction. The resulting transient network of carbon-rich melts is frozen in the mantle wedge without producing volcanism. Our results provide the first in-situ observational evidence of ongoing carbon sequestration in the upper mantle at a plate-tectonic scale. We infer that carbon sequestered during cold subduction may partly counterbalance carbon outgassed from ridges and oceanic islands. However, subducted carbon may be rapidly released during continental rifting, with global effects on long-term climate trends and the habitability of planet Earth.

The long-term carbon budget of planet Earth is largely modulated by the tectonic balance between $\mathrm{CO}_{2}$ outgassing to the atmosphere from volcanism, and carbon input to the Earth interior during subduction ${ }^{1,2}$. Carbon input into the mantle depends on the lithologies subducted ${ }^{3}$ and on physical processes, which are only partly understood, that take place in the downgoing slab and in the overlying mantle wedge ${ }^{4,5}$. Some studies suggest that little carbon can be recycled into the mantle ${ }^{2}$, whereas other studies infer that sequestration of subducted carbon in the mantle may be relevant ${ }^{1}$, at least in cooler subduction zones. However, in spite of the potentially relevant implications for climate change and planet habitability, compelling evidence of large-scale carbon storage in the Earth's upper mantle are still lacking, and it is not clear whether subducted carbon can be effectively sequestered beyond sub-arc depths over geological time scales, or not ${ }^{1,2,5}$.

We combine geodynamic reconstructions of the Adria-Europe plate boundary zone with geophysical imaging and petrological modeling to reveal large-scale carbon processes associated with a complex slab configuration. The geometry of subducted slabs are resolved using recent $P$ wave tomography models ${ }^{6}$, and include a SE-dipping European slab to the north and a SW-dipping Adriatic slab to the south (Fig. 1a). Tectonic reconstructions $^{7,8}$ suggest that Alpine subduction was active since the Cretaceous, leading to the consumption of the Alpine Tethys formerly separating the Adriatic and European paleomargins (Fig. 1a,b). Adriatic subduction initially developed south of Corsica, and progressively propagated northward during the Eocene-Oligocene ${ }^{8}$. Since the late Oligocene, the interaction between the SE-dipping European slab and the northward shifting Adriatic slab

${ }^{1}$ Department of Earth and Environmental Sciences, University of Milano-Bicocca, Milano, Italy. ${ }^{2}$ Department of Earth Sciences, University of Torino, Torino, Italy. ${ }^{3}$ Center for Research Excellence in Science and Technology (CREST), North Carolina Central University, Durham, NC, USA. ${ }^{4}$ Department of Mathematics and Geosciences, University of Trieste, Trieste, Italy. ${ }^{5}$ Institute of Geophysics, China Earthquake Administration, Beijing, People's Republic of China. ${ }^{6}$ Accademia Nazionale dei Lincei, Rome, Italy. ${ }^{7}$ ISSO, Arsita, Italy. Correspondence and requests for materials should be addressed to M.G.M. (email: marco.malusa@unimib.it) or M.L.F. (email: maria.frezzotti@unimib.it) 
a

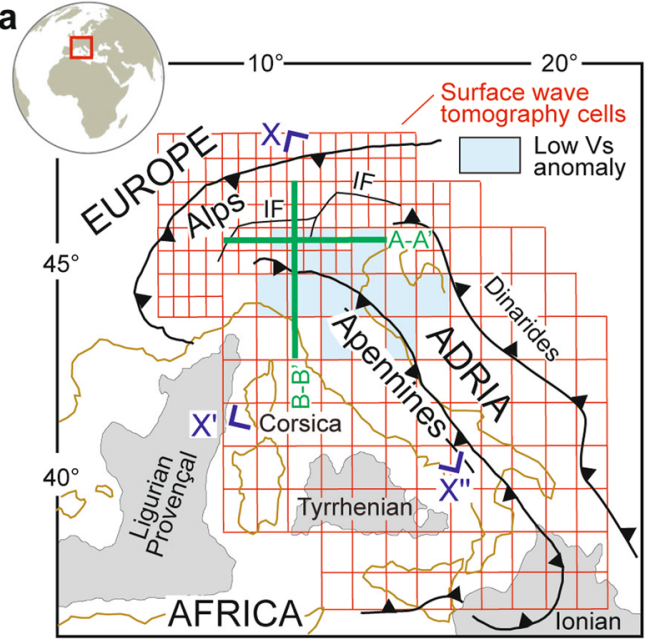

b

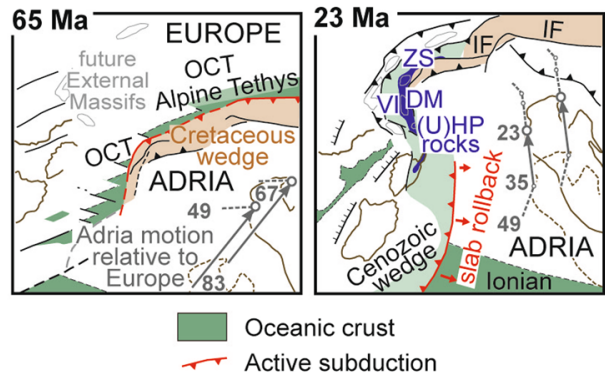

C

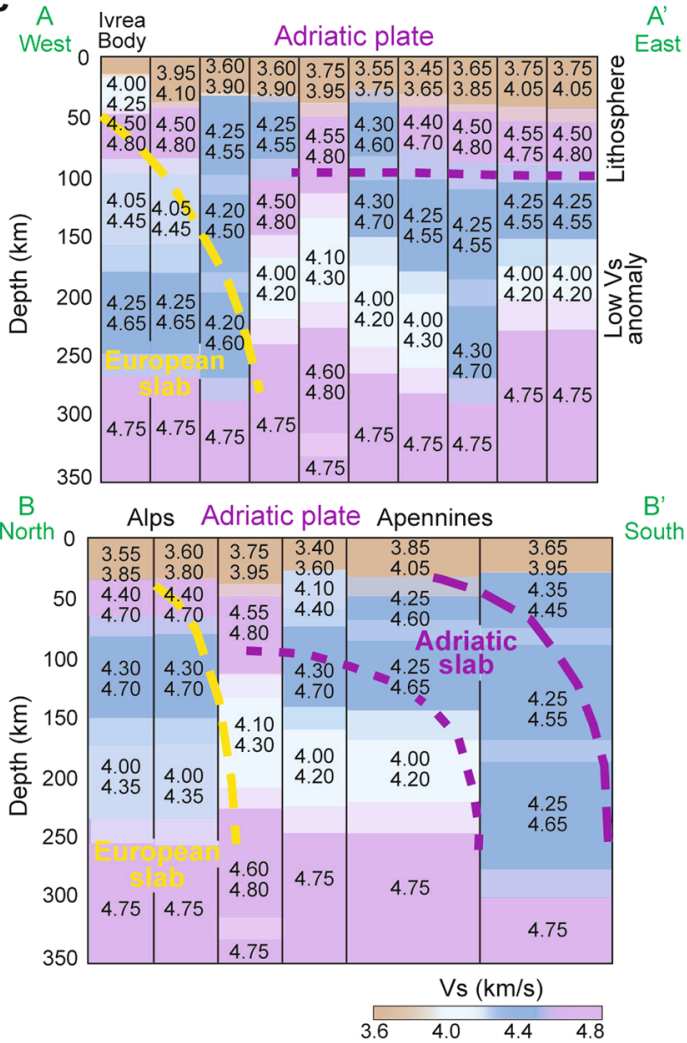

Figure 1. The low Vs anomaly in the Adriatic upper mantle. (a) Tectonic sketch map and boundaries of the cellular surface-wave tomography model of the central Mediterranean; cells showing anomalously low Vs values are marked in light blue. (b) Cenozoic evolution of Alpine subduction, grey arrows (after ref. ${ }^{8}$ ) indicate Adria trajectories relative to Europe (numbers = age in $\mathrm{Ma}$ ); (ultra)high-pressure [(U)HP] units: DM = Dora-Maira, $\mathrm{VI}=$ Viso, ZS = Zermatt-Saas; OCT = ocean-continent transition; IF = Insubric Fault. (c) Tomographic cross sections showing the low Vs anomaly (light blue) between the European and Adriatic slabs (slab structure after ref. ${ }^{6}$ ); shaded areas indicate the variability range of layer thickness. Maps and cross sections generated using Inkscape v0.91 (https://inkscape.org).

precluded any major subduction at the Alpine trench ${ }^{9}$. The Adriatic slab began rolling back in the Neogene, leading to the opening of the Ligurian-Provençal and Tyrrhenian backarc basins ${ }^{10}$.

The Alpine subduction wedge mainly consists of (ultra)high-pressure [(U)HP] metamorphic rocks with mineral assemblages that formed during very cold subduction $\left(5-8^{\circ} \mathrm{C} / \mathrm{km}\right)^{8}$. Above the remnants of the European slab, body wave tomography models revealed a prominent low-velocity anomaly ${ }^{6,11,12}$ that was tentatively interpreted to result from fluids released by dehydration reactions during the early stages of Alpine subduction ${ }^{11}$. Hypotheses concerning the origin, age and composition of these fluids still remain highly debatable. A reliable analysis of the potential spatial and time relationships between seismic velocity anomalies, slab structure and mineral reactions along the slab interface and in the overlying mantle wedge requires a higher resolution image of the velocity structure of the supra-slab mantle, which is not provided by available body wave tomography models.

\section{The velocity structure of the supra-slab mantle}

Here, we use a cellular tomographic model based on seismic surface waves (see Methods and Fig. 1a) to explore the shear wave velocity (Vs) structure of the supra-slab Adriatic mantle in much greater detail as compared with previous work $\mathrm{rk}^{6,11,12}$. Surface wave tomography, unlike body wave tomography, does not require an a priori reference model ${ }^{13-15}$. Our model provides a reliable estimate of the Vs layered structure and its uncertainties to $\sim 350 \mathrm{~km} \mathrm{depth}^{14,16,17}$. The slab structure provided by body wave tomography ${ }^{6}$, since its uncertainties are not easily quantifiable ${ }^{15}$, can be used as ancillary information. As shown in Fig. 1c, our tomographic model highlights a sharp velocity drop at $\sim 100 \mathrm{~km}$ depth that is particularly evident in cross section A-A'. We interpret this drop to mark the boundary between the Adriatic lithosphere and the underlying asthenospheric mantle. The thickness of the Adriatic lithosphere is similar to the thickness of the European lithosphere, as independently constrained by array analysis of seismic surface waves ${ }^{18}$. An additional strong velocity drop is observed in the Adriatic asthenospheric mantle at $\sim 180 \mathrm{~km}$ depth (Fig. 1c). This low velocity anomaly $(\mathrm{Vs}=4.0-4.2 \mathrm{~km} / \mathrm{s})$ is recognised over an area of $\sim 10^{5} \mathrm{~km}^{2}$ (light blue cells in Fig. 1a), and is exclusively found within the mantle sandwiched between the European and the Adriatic slabs (yellow and purple colours, respectively, in Fig. 1c). The spatial relationships between this anomaly and the nearby slabs imply that the anomaly formed when the slab structure was already fixed. Recent palinspastic reconstructions ${ }^{8}$ and available plate motion constraints (grey arrows in Fig. 1b) 


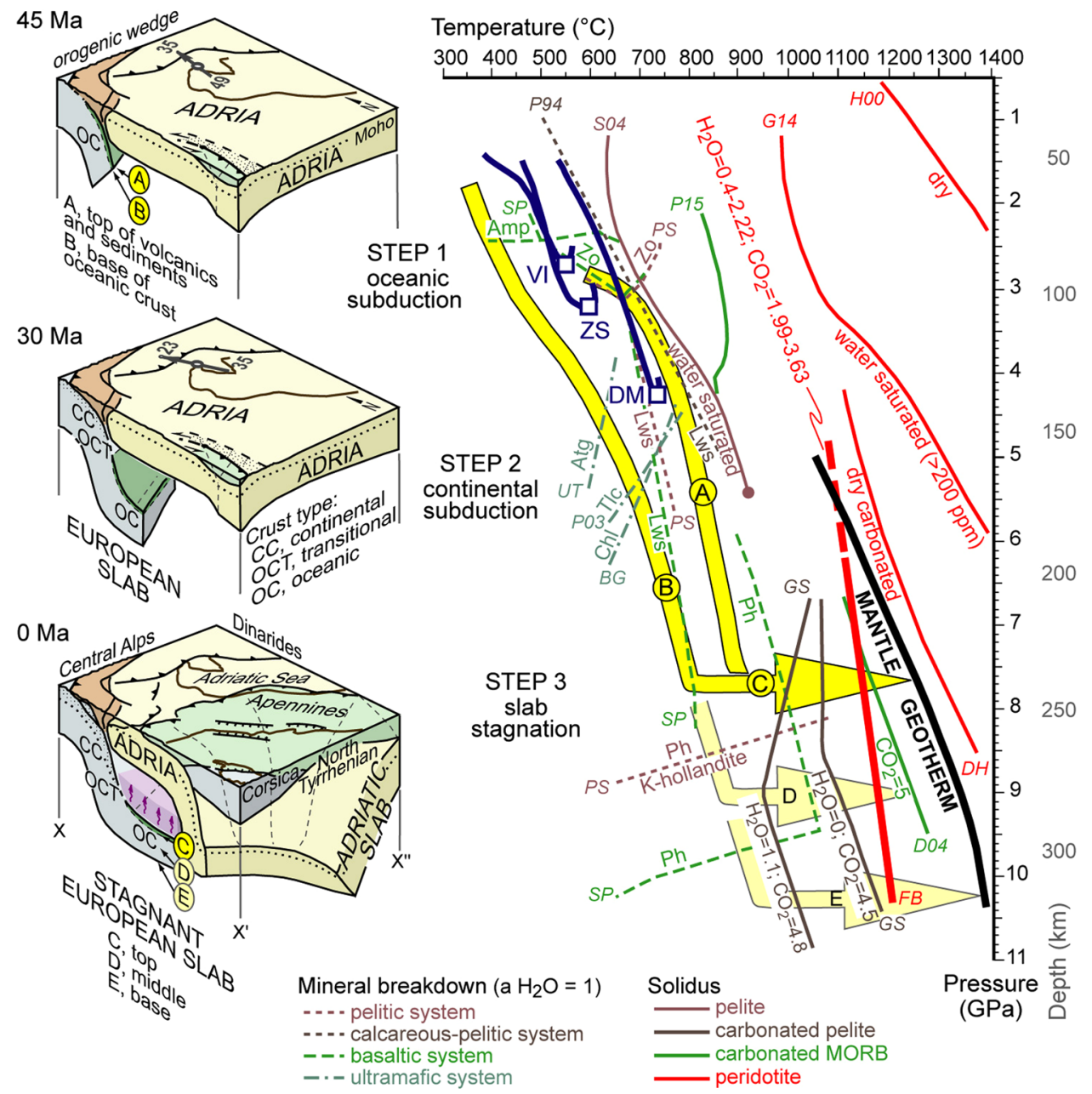

Figure 2. 3D reconstruction of Alpine subduction and associated mineral reactions. Prograde pressuretemperature paths of exhumed (U)HP rocks (blue lines) ${ }^{19-21}$ are consistent with modelled pressure-temperature paths of modern subduction zones (yellow arrows A and B, from ref. ${ }^{25}$ ). Cold subduction favours the preservation of carbonates and hydrous minerals (e.g. phengite) to asthenospheric depths. Progressive increase in slab temperature (yellow arrow C) towards mantle values (black line, from ref. ${ }^{27}$ ) during slab stagnation induces melting of metasediments $\left(\mathrm{GS}^{45}, \mathrm{~S}^{4} 4^{46}\right)$ and carbonated metabasics (D04 $\left.{ }^{47}\right)$. Consequent generation of carbonate-rich hydrous-silicate melts determines supersolidus conditions in the mantle-wedge peridotite (thick red line $\mathrm{FB}^{48,49}$ ) at depths as shallow as $\sim 180 \mathrm{~km}$. Keys to mineral breakdown and solidus curves. Continuous lines: in brown, wet solidus and second critical end-point of pelite (S04) $)^{46}$; in grey, carbonated pelite solidi with bulk $\mathrm{H}_{2} \mathrm{O}$ and $\mathrm{CO}_{2}$ contents in wt $\%(\mathrm{GS})^{45}$; in green, part of the solidus of carbonated basaltic eclogite (D04) ${ }^{47}$ and hydrated and carbonated gabbro $(\mathrm{P} 15)^{50}$; in red, solidi of dry peridotite $(\mathrm{H} 00)^{51}$, water saturated peridotite $(\mathrm{G} 14)^{52}$, dry carbonated peridotite $(\mathrm{DH})^{53}$, and potassium-rich hydrated carbonated peridotite (FB, as compiled by ref. ${ }^{54}$ : $0.40-0.63 \mathrm{wt} \% \mathrm{H}_{2} \mathrm{O}$ and $1.99-3.21 \mathrm{wt} \% \mathrm{CO}_{2}$ after ref. ${ }^{48} ; 2.22 \mathrm{wt} \% \mathrm{H}_{2} \mathrm{O}$ and $3.63 \mathrm{wt} \% \mathrm{CO}_{2}$ after ref. ${ }^{49}$, the dashed part is inferred). Dashed lines: parts of amphibole-, zoisite-, lawsonite- and phengite-out curves in basalts (SP) ${ }^{55}$ and pelites/greywakes (PS) ${ }^{56}$; part of the lawsonite-out curve in a CASH system (P94 $)^{57}$; part of antigorite-, talc- and chlorite-out curves in ultramafic system $\left(\mathrm{UT}^{58}, \mathrm{P}^{5} 3^{59}, \mathrm{BG}^{60}\right)$. Image generated using Inkscape v0.91 (https://inkscape.org).

indicate that the slab configuration observed today was acquired during the Neogene (see cartoons in Fig. 2). This low-velocity anomaly is thus a recent feature of the Adriatic upper mantle. It could be the result of melts released in the Neogene from the stagnant European slab, during progressive thermal reequilibration with the adjacent mantle. No mantle plume cutting across the European slab is documented by recent body wave tomographic models ${ }^{6,12}$, ruling out the potential role of deeper mantle processes in determining the observed reduction in shear wave velocities.

\section{Carbon evolution during Alpine subduction}

Carbon release to the mantle wedge strongly depends on the composition and metamorphic evolution of the subducting lithosphere. Based on the composition of the oceanic slivers originally belonging to the Alpine Tethys, and now accreted in the Alpine belt, various proportions of serpentinised mantle, basalts and sedimentary rocks 
- such as cherts, limestones, greywackes and (calcareous) pelites - were subducted at the Alpine trench since the Cretaceous $^{7,8}$. Direct evidence of the metamorphic evolution of these rocks during oceanic subduction (step 1 in Fig. 2) is provided by the prograde P-T paths of exhumed oceanic (U)HP rocks such as the Viso (VI in Figs 1, 2) ${ }^{19}$ and Zermatt-Saas (ZS in Figs 1, 2) ${ }^{20}$ metaophiolites. The coesite-bearing ophiolitic slice of Cignana, in the Zermatt-Saas unit, was subducted to $\sim 110 \mathrm{~km}$ depth $\sim 45 \mathrm{Myr}$ ago. These rocks experienced breakdown of amphibole (Amp) and zoisite (Zo) in metabasics ${ }^{20}$, and likely breakdown of zoisite in metasediments, but dehydration of antigorite (Atg) in ultrabasic rocks was largely incomplete. Dehydration was also incomplete during subsequent continental subduction (step 2 in Fig. 2), as documented by the coesite-bearing continental slice of Brossasco-Isasca, in the Dora-Maira unit (DM in Figs 1 and 2) ${ }^{21}$, which reached depths of $\sim 140 \mathrm{~km} \sim 35 \mathrm{Myr}$ ago. The Brossasco-Isasca rocks experienced breakdown of zoisite in metapelites, of zoisite and antigorite in impure marbles, and of chlorite (Chl), talc (Tlc) and phlogopite in $\mathrm{Mg}$-metasomatic rocks ${ }^{21,22}$, but the low paleogeothermal gradient during subduction prevented the breakdown of phengite $(\mathrm{Ph})$.

Carbonates can escape breakdown during cold subduction ${ }^{23}$. In the Alpine subduction zone, dissolution of part of the carbonates was favoured by aqueous solutions released at (U)HP conditions ${ }^{24}$. However, limited metamorphic carbonate destabilisation in continental rocks ${ }^{22}$ suggests that major amounts of subducted carbonates survived decarbonation $\left(\mathrm{CO}_{2}\right.$-rich fluids or melts release) and were probably dragged beyond $120-140 \mathrm{~km}$ depths by the downgoing slab.

According to geophysical evidence and paleotectonic reconstructions $\mathrm{s}^{6,8}$, over $200 \mathrm{~km}$ of Tethyan oceanic lithosphere was consumed at the Alpine trench since the Cretaceous, but only a limited amount of this lithosphere was accreted in the Alpine belt and escaped deep subduction. The metamorphic evolution of these rocks at asthenospheric depths, in the lack of direct petrologic evidence, can be inferred by considering the computational thermal models formulated for modern subduction zones ${ }^{25}$. Predicted slab geothermal gradients in the uppermost mantle are largely consistent with those recorded by exhumed Alpine rocks at the same depth range. The yellow arrows $A$ and $B$ in Fig. 2 indicate the temperature-depth trajectories modelled for the Lesser Antilles subduction zone (case D80 in ref. ${ }^{25}$ ). They show temperatures at the top of the slab that are similar to those recorded by the Brossasco-Isasca slice. Along these cold subduction paths, the breakdown of lawsonite (Lws) in metabasics is predicted at depths larger than $100 \mathrm{~km}$, and dehydration of ultramafic rocks is possibly completed at depths no greater than $180 \mathrm{~km}$. Substantial amounts of aqueous fluids, potentially able to destabilise carbonates, are thus released at sub-arc depths ${ }^{21,26}$. However, carbonates and hydrous minerals (i.e., phengite) are stable both in metasediments and metabasics along the considered subduction paths, which run within the subsolidus field parallel to the main solidus slopes of carbonated and/or hydrous crustal rocks to depth of 200-250 km (Fig. 2).

\section{Carbon sequestration in the Alpine mantle wedge}

Since the late Oligocene, the stagnant European slab underwent progressive thermal reequilibration towards ambient mantle conditions ${ }^{27}$ (thick black line in Fig. 2). The expected temperature increase at the slab interface (yellow arrow $\mathrm{C}$ in Fig. 2) promoted further dehydration of metabasics at $220-250 \mathrm{~km}$ depth, via breakdown of lawsonite (at $\sim 800^{\circ} \mathrm{C}$ ) and phengite $\left(\right.$ at $\sim 1000^{\circ} \mathrm{C}$ ), and finally induced breakdown of carbonates in both calcareous metasediments (at $\sim 1000^{\circ} \mathrm{C}$ ) and carbonated metabasics (at $\sim 1200^{\circ} \mathrm{C}$ ) (step 3 in Fig. 2).

In the asthenospheric mantle, subducted oxidised carbon can be present as crystalline carbonate or as carbonate-rich melts ${ }^{28}$. Owing to the slope of the carbonated hydrous peridotite solidus (thick red line in Fig. 2), carbon-rich supercritical fluids generated along the interface of the stagnant European slab could have induced melting in the overlying mantle wedge. Low density and low viscosity allow efficient extraction and rising of carbonate-rich melts in the Adriatic asthenosphere. We interpret the drop in seismic shear wave velocities observed at depths larger than $180 \mathrm{~km}$ (Fig. 3a) as an effect of the resulting melt network. If melt completely wets grain-boundaries, as demonstrated by laboratory studies for the forsterite $+\mathrm{H}_{2} \mathrm{O}$ system at $\mathrm{P}>7 \mathrm{GPa}\left(\right.$ ref. $\left.{ }^{29}\right)$, even a small amount of melt (e.g., 1\%) can produce remarkable velocity drops of $20-30 \%\left(\right.$ ref. $\left.^{30}\right)$.

The key observation of Fig. 2 is that the mantle geotherm crosses the carbonated hydrous peridotite solidus at about $5.6 \mathrm{GPa}$ and $1100^{\circ} \mathrm{C}$. Therefore, mobile carbonate-melt stability is limited to a depth of $\sim 180 \mathrm{~km}$. Above this depth, attainment of peridotite subsolidus conditions requires that carbon is sequestered as magnesite ${ }^{28}$, escaping immediate release by magmatic activity (Fig. 3a). The seismic velocities in the resulting mantle do not show variations, in agreement with the geophysical record (Fig. 1).

A different process of carbon sequestration would be expected if the cold stagnant slab was reequilibrated at greater depths. In a mantle where oxygen fugacity is controlled by $\mathrm{Fe}^{2+} / \mathrm{Fe}^{3+}$ exchange, metal saturation is predicted at depths larger than $200-250 \mathrm{~km}^{331}$ (Fig. 3a). Since carbonates are not stable at these redox conditions, carbon would be immediately reduced to immobile diamond ${ }^{3}$, and would be sequestered in the mantle. We predict that at depths greater than $200-250 \mathrm{~km}$, there would be no apparent drop in shear wave velocity.

\section{Implications for carbon budgets and long-term climate trends}

The petrological and geodynamical interpretation of the velocity structure of the Alpine mantle wedge suggests that carbon sequestration is active. The Alpine case is particularly favourable for the detection of long-term carbon storage by seismic methods, but the same process may take place without any clear-cut geophysical evidence in other cold subduction zones, for example around the Pacific ${ }^{4}$. This suggests that our model carbon evolution (Fig. 3a) may well have general validity.

Freezing of carbonate-rich melts above $\sim 180 \mathrm{~km}$ under the Alps implies that carbon is effectively sequestered in the upper mantle without immediate release. Subducted carbon is possibly remobilised at a later stage of the plate tectonic evolution, for example by thermal increase or redox melting of carbonated peridotites ${ }^{3}$ or adiabatic decompression during continental breakup at the onset of a new Wilson cycle ${ }^{5}$ (Fig. 3b). These processes may occur hundreds of millions of years after subduction ceases, leading to major heterogeneities in the upper-mantle carbon content, with possible formation of large-scale carbon reservoirs at asthenospheric depths. 


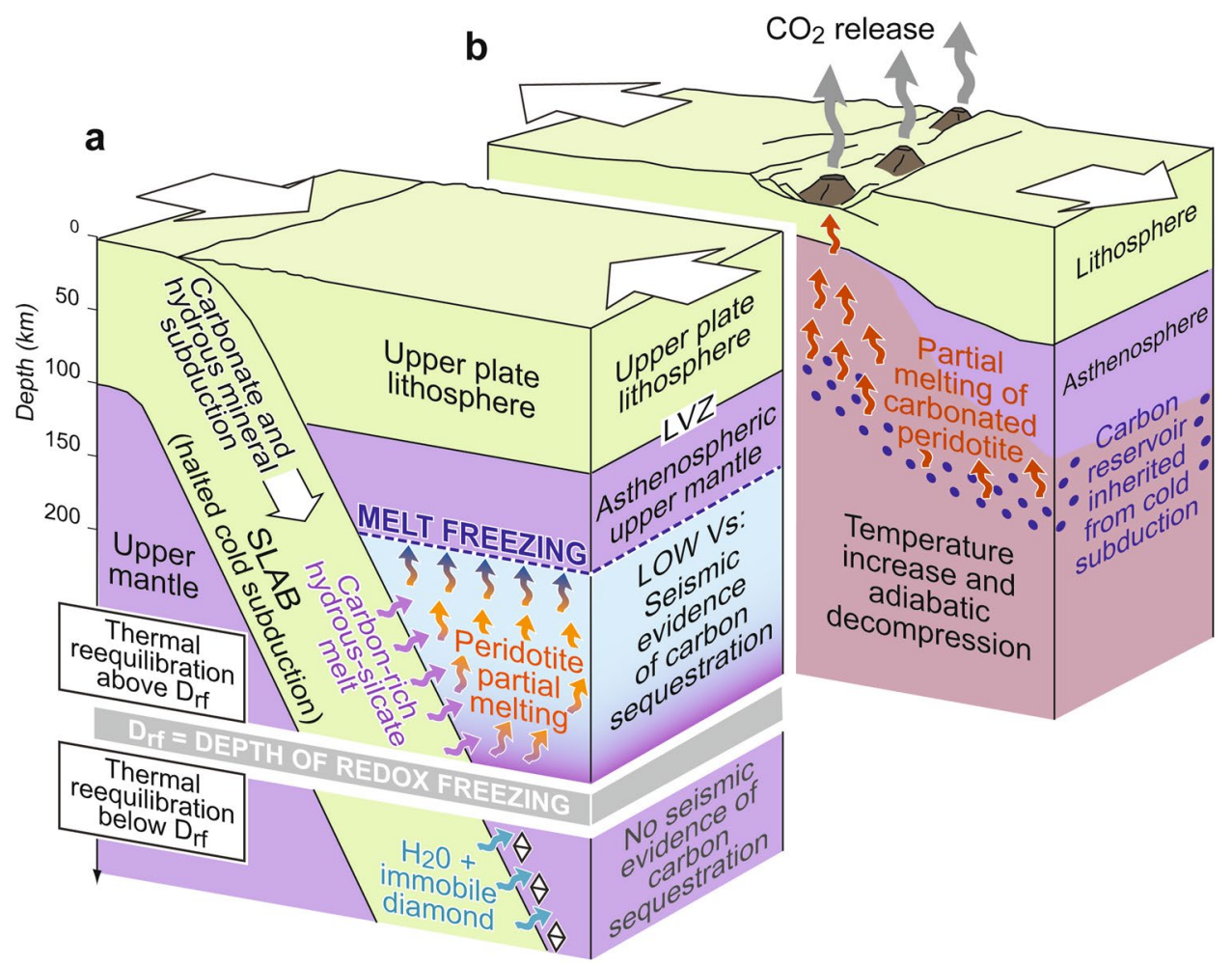

Figure 3. Seismic evidence of carbon sequestration in the upper mantle by cold subduction and delayed $\mathrm{CO}_{2}$ release. (a) Breakdown of carbonates and hydrous minerals during thermal reequilibration of a cold stagnant slab generates carbon-rich hydrous-silicate melts, that infiltrate the overlying mantle wedge inducing partial melting of the mantle peridotite. The resulting network of carbonate-silicate melt reduces the seismic shear wave velocity (Vs) at depths as shallow as $\sim 180 \mathrm{~km}$, where this carbon-rich melt is solidified. The low Vs layer in the supra-slab asthenosphere thus provides direct evidence of long-term carbon capture and storage in the upper mantle. However, when breakdown of carbonates and hydrous minerals occurs below the depth of redox freezing, carbon sequestration has no seismic evidence because carbon is immediately converted to diamond, and released fluids cannot activate partial melting. (b) Carbon stored in the asthenospheric mantle during cold subduction is remobilised at a later stage of the plate tectonic evolution, leading to rapid $\mathrm{CO}_{2}$ outgassing with potential harmful effects for the biosphere. Image generated using Inkscape v0.91 (https://inkscape.org).

It has been recently proposed that massive $\mathrm{CO}_{2}$ degassing in active rift systems would provide a viable link between continental fragmentation and long-term climate change ${ }^{32,33}$. In the East African rift system, extrapola-

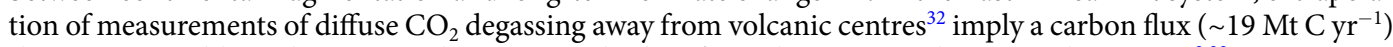
that is comparable to the present-day emission budget from the entire mid-ocean ridge system ${ }^{2,32}$. During past episodes of supercontinent breakup, widespread continental rifting may have determined even greater short-term carbon outputs of hundreds of Megatons per year ${ }^{33,34}$.

Peaks of atmospheric $\mathrm{CO}_{2}$ concentrations recorded through Earth history during supercontinent breakup events are possibly linked to mass extinctions ${ }^{35}$. If our model of carbon capture and storage by cold subduction is accurate, previous estimates of carbon release during continental rifting ${ }^{32}$ may just provide a lower bounding estimate on Earth's $\mathrm{CO}_{2}$ emissions during future episodes of continental breakup. We can thus predict peaks of $\mathrm{CO}_{2}$ outgassing higher than in the past, because carbon sequestration in the upper mantle has been favoured during the Phanerozoic by the dominantly cold nature of subduction zones ${ }^{4,5}$.

Natural $\mathrm{CO}_{2}$ emissions are not comparable with present-day anthropogenic contributions from fossil fuels

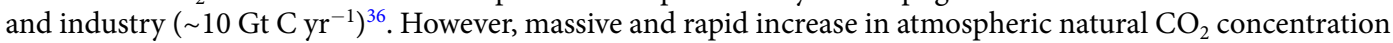
over geologic timescales, as predicted by our model, may have harmful effects, determining a sharp temperature rise that would adverse the habitability of our planet.

The potential occurrence of recycled carbon within the upper mantle of continental rift zones supports the conclusion that the Earth's carbon cycle is not limited to subduction zones ${ }^{1,2,53}$. This implies that the carbon cycle is imbalanced on the time scale of a single plate-tectonic cycle. Whereas mantle carbon sequestration during cold subduction may partly counterbalance the long-term carbon increase in the lithosphere, oceans, and atmosphere determined by $\mathrm{CO}_{2}$ outgassed from ridges and oceanic islands ${ }^{2}$, massive recycled-carbon release from upper-mantle reservoirs is expected during supercontinent breakup.

\section{Methods}

The Vs cellular model with a $0.5^{\circ} \times 0.5^{\circ}$ lateral resolution utilised in this work is a refinement of the $1^{\circ} \times 1^{\circ}$ cellular model, based on the inversion of dispersion data, presented by Brandmayr et al. ${ }^{14}$. The following methods are 
applied in sequence: (a) frequency-time analysis, (b) surface wave tomography, (c) "hedgehog" non-linear inversion of cellular dispersion curves, and (d) optimisation of the non-linearly inverted models to define the preferred model. Our $0.5^{\circ} \times 0.5^{\circ}$ model exploits the database of project EuCrust $07^{37}$ to define the physical properties (Vs and density) and the thickness of the sedimentary cover, the average seismic velocity of the upper crust, and the depth of the Conrad discontinuity.

FTAN analysis. The seismic record from national and international seismic networks is analysed by an interactive group velocity - period filtering method $(\mathrm{FTAN})^{38}$, which uses multiple narrow-band Gaussian filters and maps the waveform record in a two-dimensional domain: time (group velocity) - frequency (periods). The measurement of group velocity of Rayleigh and/or Love waves is performed on the envelope of the surface-wave train across a broad period band from fractions to hundreds of seconds. Based on available information on event hypocenters $^{39}$, we considered epicenter-to-station paths shorter than $3000 \mathrm{~km}$ to get reliable measurements of group velocity at periods ranging from 5 to $80 \mathrm{~s}$. Published phase-velocity measurements for Rayleigh waves in the 15 to $150 \mathrm{~s}$ period range are additionally considered to increase the penetration depth of the considered data set.

Surface wave tomography. We use the two-dimensional tomography based on the Backus-Gilbert method to determine the local values of the group and/or phase velocities for a set of periods ${ }^{40}$, and map horizontal (at a specific period) and vertical (at a specific grid knot) variations. Local values of group and phase velocities are calculated on a predetermined grid of $1^{\circ} \times 1^{\circ}$ for set of periods in the range from $5 \mathrm{~s}$ to $80 \mathrm{~s}$ for group velocities and from $15 \mathrm{~s}$ to $150 \mathrm{~s}$ for phase velocities and determine the vertical resolving power of the dataset. The lateral resolution of the tomographic maps is defined as the average size $(\mathrm{L})$ of the equivalent smoothing area and its elongation. The local dispersion curves are assembled at each grid knot from the tomographic maps. The group and/or phase velocity value is included in the dispersion curve if $\mathrm{L}$ is below a threshold specific of the period $(\mathrm{L}<300 \mathrm{~km}$ at $5 \mathrm{~s}$ and $<600 \mathrm{~km}$ at $80 \mathrm{~s}$ for group velocities; $\mathrm{L}<500 \mathrm{~km}$ at $15 \mathrm{~s}$ and $<800 \mathrm{~km}$ at $80 \mathrm{~s}$ for phase velocities) and the stretching of the averaging area of all considered values is $<1.6$. Each cellular dispersion curve is then calculated as the average of the local curves at the four corners of the cell, and the single point error for each value at a given period is estimated as the average of the measurement error at this period and the standard deviation of the dispersion values at the four corners. The value of group velocity at $80 \mathrm{~s}$ is calculated as an average between our tomography results and the results of a global study ${ }^{41}$, and the single point error for group velocity at this period is estimated as the r.m.s. of the errors of our data and those of the global data set. The r.m.s. for the whole dispersion curves (group or phase velocity) are routinely estimated as $60-70 \%$ of the average of the single point errors of the specific cellular curve ${ }^{13}$.

"Hedgehog" non-linear inversion. The cellular dispersion curves compiled from surface wave tomography are inverted by the "hedgehog" non-linear inversion method ${ }^{13,17}$. In the inversion scheme, Vs and thickness are the independent parameters, $\mathrm{Vp}$ is dependent on $\mathrm{Vs}$ (in general $\mathrm{Vp} / \mathrm{Vs}=3^{1 / 2}$ ), and density is determined according to the Nafe-Drake relation ${ }^{42,43}$. The group and phase velocities of the Rayleigh waves (fundamental mode) are computed for each tested structural model. To avoid overinterpretation of the inversion results, the details allowed in the structural models are consistent with the resolving power of the inverted data set ${ }^{17}$. The model is accepted if the difference between the computed and measured values at each period are less than the single point error at the relevant period, and if the r.m.s. values for the whole group and phase velocity curves are less than the given limits.

Optimisation. All the solutions for each cell are simultaneously processed with an optimised smoothing method to select the representative solution that minimises the local lateral velocity gradient ${ }^{16}$. Three optimisation algorithms (Local Smoothness Optimisation, Global Smoothness Optimisation and Global Flatness Optimisation) are applied hierarchically to search for the minimising solution within five neighbouring cells, along a row of cells, and through the whole study area ${ }^{14,16}$. Solutions for cells bordering the $0.5^{\circ} \times 0.5^{\circ}$ study area are fixed according to the $1^{\circ} \times 1^{\circ}$ model. Results are appraised using independent dataset concerning Moho depth and heat flow. Vp values from the literature ${ }^{44}$ are used to reduce the uncertainty ranges of Vs in each layer of the final model, by keeping a $\mathrm{Vp} / \mathrm{Vs}$ ratio in the mantle as close as possible to 1.82 .

\section{References}

1. Dasgupta, R. \& Hirschmann, M. M. The deep carbon cycle and melting in Earth's interior. Earth Planet. Sci. Lett. 298, 1-13 (2010).

2. Kelemen, P. B. \& Manning, C. E. Reevaluating carbon fluxes in subduction zones, what goes down, mostly comes up. Proc. Natl. Acad. Sci. 112, E3997-E4006 (2015)

3. Rohrbach, A. \& Schmidt, M. W. Redox freezing and melting in the Earth's deep mantle resulting from carbon-iron redox coupling. Nature 472, 209-212 (2011).

4. Abers, G. A., van Keken, P. E. \& Hacker, B. R. The cold and relatively dry nature of mantle forearcs in subduction zones. Nat. Geosci. 10(5), 333-337 (2017).

5. Dasgupta, R. Ingassing, storage, and outgassing of terrestrial carbon through geologic time. Rev. Mineral. Geochem. 75(1), 183-229 (2013).

6. Zhao, L. et al. Continuity of the Alpine slab unraveled by high-resolution P wave tomography. J. Geophys. Res. 121, 8720-8737 (2016).

7. Handy, M. R. et al. Reconciling plate-tectonic reconstructions of Alpine Tethys with the geological-geophysical record of spreading and subduction in the Alps. Earth-Sci. Rev. 102, 121-158 (2010).

8. Malusà, M. G. et al. Contrasting styles of (U)HP rock exhumation along the Cenozoic Adria-Europe plate boundary (Western Alps, Calabria, Corsica). Geochem. Geophys. Geosyst. 16, 1786-1824 (2015).

9. Malusà, M. G., Anfinson, O. A., Dafov, L. N. \& Stockli, D. F. Tracking Adria indentation beneath the Alps by detrital zircon U-Pb geochronology: Implications for the Oligocene-Miocene dynamics of the Adriatic microplate. Geology 44, 155-158 (2016).

10. Faccenna, C. et al. Mantle dynamics in the Mediterranean. Rev. Geophys. 52, 283-332 (2014).

11. Giacomuzzi, G., Chiarabba, C. \& De Gori, P. Linking the Alps and Apennines subduction systems: new constraints revealed by highresolution teleseismic tomography. Earth Planet. Sci. Lett. 301, 531-543 (2011). 
12. Hua, Y., Zhao, D. \& Xu, Y. P-wave anisotropic tomography of the Alps. J. Geophys. Res. 122, 4509-4528 (2017).

13. Panza, G. F., Peccerillo, A., Aoudia, A. \& Farina, B. M. Geophysical and petrological modelling of the structure and composition of the crust and upper mantle in complex geodynamic settings: the Tyrrhenian Sea and surroundings. Earth-Sci. Rev. 80, 1-46 (2007).

14. Brandmayr, E. et al The lithosphere in Italy: structure and seismicity. J. V. Expl. 36, https://doi.org/10.3809/jvirtex.2010.00224 (2010).

15. Foulger, G. R. et al. Caveats on tomographic images. Terra Nova 25, 259-281 (2013).

16. Boyadzhiev, G., Brandmayr, E., Pinat, T. \& Panza, G. F. Optimization for non-linear inverse problems. Rend. Lincei 19, 17-43 (2008).

17. Panza, G.F. In The Solution of the Inverse Problem in Geophysical Interpretation (ed. Cassinis, R.) Plenum Pub. Corp. (1981)

18. Lyu, C., Pedersen, H. A., Paul, A., Zhao, L. \& Solarino, S. \& CIFALPS Working Group. Shear wave velocities in the upper mantle of the Western Alps: new constraints using array analysis of seismic surface waves. Geophys. J. Int. 210, 321-331 (2017).

19. Angiboust, S., Langdon, R., Agard, P., Waters, D. \& Chopin, C. Eclogitization of the Monviso ophiolite (W. Alps) and implications on subduction dynamics. J. Metamorph. Geol. 30, 37-61 (2012).

20. Groppo, C., Beltrando, M. \& Compagnoni, R. The P-T path of the ultra-high pressure Lago di Cignana and adjointing high-pressure meta-ophiolitic units: insights into the evolution of the subduction Tethyan slab. J. Metamorph.Geol. 27, 207-231 (2009).

21. Frezzotti, M. L. \& Ferrando, S. The chemical behavior of fluids released during deep subduction based on fluid inclusions. Am. Mineral. 100, 352-377 (2015).

22. Ferrando, S., Groppo, C., Frezzotti, M. L., Castelli, D. \& Proyer, A. Dissolving dolomite in a stable UHP mineral assemblage: evidence from Cal-Dol marbles of the Dora-Maira Massif (Italian Western Alps). Am. Mineral. 102, 42-60 (2017).

23. Kerrick, D. M. \& Connolly, J. A. D. Metamorphic devolatilization of subducted marine sediments and the transport of volatiles into the Earth's mantle. Nature 411, 293-296 (2001).

24. Frezzotti, M. L., Selverstone, J., Sharp, Z. D. \& Compagnoni, R. Carbonate dissolution during subduction revealed by diamondbearing rocks from the Alps. Nat. Geosci. 4, 703-706 (2011).

25. Syracuse, E. M., Van Keken, P. E. \& Abers, G. A. The global range of subduction zone thermal models. Phys. Earth Planet. Inter. 183, $73-90(2010)$

26. Zheng, Y. F. \& Hermann, J. Geochemistry of continental subduction-zone fluids. Earth Pl. Sp. 66, 93 (2014).

27. Akaogi, M., Ito, E. \& Navrotsky, A. Olivine-modified spinel-spinel transitions in the system $\mathrm{MgSiO}_{4}-\mathrm{FeSiO}_{4}$-calorimetric measurements, thermochemical calculation, and geophysical application. J. Geophys. Res. 94, 15671-15685 (1989).

28. Dasgupta, R. \& Hirschmann, M. M. Partial melting experiments of peridotite $+\mathrm{CO}_{2}$ at $3 \mathrm{GPa}$ and genesis of alkalic ocean island basalts. J. Petrol. 48, 2093-2124 (2007).

29. Yoshino, T., Nishihara, Y. \& Karato, S. I. Complete wetting of olivine grain boundaries by a hydrous melt near the mantle transition zone. Earth Planet. Sci. Lett. 256, 466-472 (2007).

30. Karato, S. I. Rheology of the Earth's mantle: A historical review. Gondwana Res. 18, 17-45 (2010).

31. Frost, D. J. \& McCammon, C. A. The redox state of Earth's mantle. Annu. Rev. Earth. Planet. Sci. 36, 389-420 (2008).

32. Lee, H. et al. Massive and prolonged deep carbon emissions associated with continental rifting. Nat. Geosci. 9, 145 (2016).

33. Foley, S. F. \& Fischer, T. P. An essential role for continental rifts and lithosphere in the deep carbon cycle. Nat. Geosci. 10, 897 (2017).

34. Brune, S., Williams, S. E. \& Müller, R. D. Potential links between continental rifting, $\mathrm{CO}_{2}$ degassing and climate change through time. Nat. Geosci. 10, 941 (2017)

35. Bond, D. P. G. \& Wignall, P. B. Large igneous provinces and mass extinctions: an update. Geol. Soc. Am. Spec. Pap. 55, 29-55 (2014).

36. Le Quéré, C. et al. Global carbon budget 2017. Earth System Sci. Data Disc., 1-79 (2017).

37. Tesauro, M., Kaban, M. K. \& Cloetingh, S. EuCRUST-07: a new reference model for the European crust. Geophys. Res. Lett. 35, L05313 (2008).

38. Levshin, A.L. et al. In Surface Seismic Waves in LaterallyInhomogeneous Earth (ed. Keilis-Borok VI) Kluiwer Publ. House (1989).

39. ISC. Seismicity-depth distribution. International Seismological Centre, Available at: http://www.isc.ac.uk (2007).

40. Yanovskaya, T. B., Panza, G. F., Ditmar, P. D., Suhadolc, P. \& Mueller, S. Structural heterogeneity and anisotropy based on 2-D phase velocity patterns of Rayleigh waves in WesternEurope. Atti Acad. Naz. Lincei 1, 127-135 (1990).

41. Ritzwoller, M. \& Levshin, A. L. Eurasian surface wave tomography: group velocities. J. Geophys. Res. 103, 4839-4878 (1998).

42. Ludwig, W. J., Nafe, J. E. \& Drake, C. L. Seismic refraction. The Sea, vol. 4 (Part 1). Wiley-Intersci., New York, pp 53-84 (1970).

43. Fowler, C. M. R. The Solid Earth. An introduction to global geophysics. Cambridge Univ. Press, 700 pp (1995).

44. Piromallo, C. \& Morelli, A. P wave tomography of the mantle under the Alpine-Mediterranean area. J. Geophys. Res. 108, 2065-2088 (2003).

45. Grassi, D. \& Schmidt, M. W. The Melting of Carbonated Pelites from 70 to 700 km Depth. J. Petrol. 52, 765-789 (2011).

46. Schmidt, M. W., Vielzeuf, D. \& Auzanneau, E. Melting and dissolution of subducting crust at high pressures: the key role of white mica. Earth Planet. Sci. Lett. 228, 65-84 (2004).

47. Dasgupta, R., Hirschmann, M. M. \& Withers, A. C. Deep global cycling of carbon constrained by the solidus of anhydrous, carbonated eclogite under upper mantle conditions. Earth Planet. Sci. Lett. 227, 73-85 (2004).

48. Foley, S. F. et al. The composition of near-solidus melts of peridotite in the presence of $\mathrm{CO}_{2}$ and $\mathrm{H}_{2} \mathrm{O}$ between 40 and 60 kbar. Lithos 112, 274-283 (2009).

49. Brey, G. P., Bulatov, V. K. \& Girnis, A. V. Influence of water and fluorine on melting of carbonated peridotite at 6 and $10 \mathrm{GPa}$. Lithos 112, 249-259 (2009).

50. Poli, S. Carbon mobilized at shallow depths in subduction zones by carbonatitic liquids. Nat. Geosci. 8, 633-636 (2015).

51. Hirschmann M.M. Mantle solidus: experimental constraints and the effects of peridotite composition. Geochem. Geophys. Geosyst. 1, https://doi.org/10.1029/2000GC000070 (2000).

52. Green, D. H. et al. Experimental study of the influence of water on melting and phase assemblages in the upper mantle. J. Petrol. 55, 2067-2096 (2014).

53. Dasgupta, R. \& Hirschmann, M. M. Melting in the Earth's deep upper mantle caused by carbon dioxide. Nature 440, 659-662 (2006).

54. Grassi, D. \& Schmidt, M. W. Melting of carbonated pelites at 8-13 GPa: generating K-rich carbonatites for mantle metasomatism. Contrib. Mineral. Petrol. 162, 169-191 (2011).

55. Schmidt, M. W. \& Poli, S. Experimentally based water budgets for dehydrating slabs and consequences for arc magma generation. Earth Planet. Sci. Lett. 163, 361-379 (1998).

56. Poli, S. \& Schmidt, M. W. Petrology of subducted slabs. Annu. Rev. Earth Planet. Sci. 30, 207-235 (2002)

57. Pawley, A. R. The pressure and temperature stability limits of lawsonite: implications for $\mathrm{H}_{2} \mathrm{O}$ recycling in subduction zones. Contrib. Mineral. Petrol. 118, 99-108 (1994).

58. Ulmer, P. \& Trommsdorff, V. Phase relations of hydrous mantle subducting to $300 \mathrm{~km}$. Geochem. Soc. Spec. Pub. 6, 259-281 (1999).

59. Pawley, A. R. Chlorite stability in mantle peridotite: the reaction clinochlore + enstatite $=$ forsterite + pyrope $+\mathrm{H}_{2} \mathrm{O}$. Contrib. Mineral. Petrol. 144, 449-456 (2003).

60. Bose, K. \& Ganguly, J. Experimental and theoretical studies of the stabilities of talc, antigorite and phase A at high pressures with applications to subduction processes. Earth Planet. Sci. Lett. 136, 109-121 (1995). 


\section{Acknowledgements}

Funding was provided by Project MIUR-PRIN "The subduction and exhumation of the continental lithosphere: their effects on the structure and evolution of the orogens" and Milano-Bicocca University; E.B. acknowledges partial financial support by SHARM project (ESF - Regione FVG). M.G.M and M.L.F. acknowledge discussions with Suzanne L. Baldwin. This article is an outcome of Project MIUR - Dipartimenti di Eccellenza 2018-2022.

\section{Author Contributions}

E.B., F.R. and G.F.P. produced the seismic model; M.G.M. reconstructed the geodynamic framework; S.F. summarised the metamorphic evolution of the European slab; M.L.F. interpreted carbon processes in the upper mantle; M.G.M., M.L.F. and S.F. interpreted the results and wrote the manuscript with inputs from E.B., F.R. and G.F.P.

\section{Additional Information}

Competing Interests: The authors declare no competing interests.

Publisher's note: Springer Nature remains neutral with regard to jurisdictional claims in published maps and institutional affiliations.

(c) (i) Open Access This article is licensed under a Creative Commons Attribution 4.0 International License, which permits use, sharing, adaptation, distribution and reproduction in any medium or format, as long as you give appropriate credit to the original author(s) and the source, provide a link to the Creative Commons license, and indicate if changes were made. The images or other third party material in this article are included in the article's Creative Commons license, unless indicated otherwise in a credit line to the material. If material is not included in the article's Creative Commons license and your intended use is not permitted by statutory regulation or exceeds the permitted use, you will need to obtain permission directly from the copyright holder. To view a copy of this license, visit http://creativecommons.org/licenses/by/4.0/.

(C) The Author(s) 2018 